A PRELIMINARY SEISMICITY STUDY OF THE SOUTHERN NEVADA REGION FOR THE MONTH OF OCTOBER 1972

U. S. DEPARTMENT OF COMMERCE NATIONAL OCEANIC AND ATMOSPHERIC ADMINISTRATION

EARTH SCIENCES LABORATORIES 


\section{DISCLAIMER}

This report was prepared as an account of work sponsored by an agency of the United States Government. Neither the United States Government nor any agency Thereof, nor any of their employees, makes any warranty, express or implied, or assumes any legal liability or responsibility for the accuracy, completeness, or usefulness of any information, apparatus, product, or process disclosed, or represents that its use would not infringe privately owned rights. Reference herein to any specific commercial product, process, or service by trade name, trademark, manufacturer, or otherwise does not necessarily constitute or imply its endorsement, recommendation, or favoring by the United States Government or any agency thereof. The views and opinions of authors expressed herein do not necessarily state or reflect those of the United States Government or any agency thereof. 


\section{DISCLAIMER}

Portions of this document may be illegible in electronic image products. Images are produced from the best available original document. 


\section{LEGAL NOTICE}

This report was preparcd аз an account of wurk spunsured by the United States Government. Neither the United States nor the United States Atomic Energy Commission, nor any of their employees, nor any of their contractors, subcontractors, or their employees, makes any warranty, express or implied, or assumes any legal liability or responsibility for the accuracy, completeness, or usefulness of any information, apparatus, product or process disclosed, or represents that its use would not infringe privately-owned rights.

Available From The

National Technical Information Service

U. S. Department of Commerce

Springfield, Virginia 22151 
FOR THE MONTH OF OCTOBER 19.72

KENNETH C. BAYER

U. S. DEPARTMENT OF COMMERCE

NATIONAL OCEANIC AND ATMOSPHE RIC ADMINISTRA TION

EARTH SCIENCES LABORA TORIES

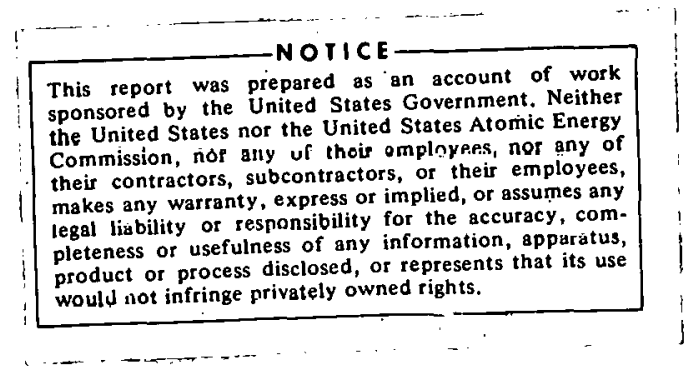

DECEMBER 1972

PREPARED FOR THE U. S. ATOMIC ENERGY COMMISSION

NEVADA OPERATIONS OFFICE

UNDER MEMORANDUM OF AGREEMENT AT(29-2)-746 
THIS PAGE

\section{WAS INTENTIONALLY LEFT BLANK}




\section{TABLE OF CONTENTS}

\section{Page}

$\begin{array}{lll}\text { ABSTRACT } & 1\end{array}$

1. INTRODUCTION .

2. DISCUSSION . 4

3. GENERAL SEISMICITY 5

4. ACKNOWLEDGMENTS 9

5. REFERENCES - 9

APPENDIX A - Hypocenter Summary A-1

TABLE 1 - Seismic Station Constants 3

FIGURES

1. Station Location Map $\quad 2$

2. Earthquakes in the Southern Nevada Region for the 6 Month of October 1972

3. Earthquakes on and Adjacent to the Nev vada Test Site Month of October 1972 


\title{
A PRELIMINARY SEISMICITY STUDY OF THE SOUTHERN NEVADA REGION FOR THE MONTH OF OCTOBER 1972
}

\author{
Kenneth C. Bayer
}

\begin{abstract}
A cooperative (ESL, Sandia Laboratories, and USGS) network of 21 seismic velocity sensitive stations is operated in the southern Nevada area; the stations are monitored by the NOAA/ESL Nevada Special Projects Party located in Las Vegas, Nevada.

The Twin Springs and Alamo areas of Nevada plus the upper termination of Death Valley in California (west of Scotty's Junction) were unusually active during the month. Two seismicity maps are included; one of the southern Nevada region and the second of the seismicity on and adjacent to the Nevada Test Site (NTS).

This is the fourth in a series of monthly seismic bulletins covering the southern Nevada region, monitored by the Las Vegas, Nevada-based Special Projects Party. The seismic data output is listed in the Hypocenter Summary (Appendix A). The listing is the result of data scaled only from the local cooperative network, and solutions determined by a local-epicenter program. A total of 93 epicenters is listed.
\end{abstract}

\section{INTRODUCTION}

This report contains a summary of earthquakes recorded by a network of 19 seismograph stations in the southern Nevada region, and 2 stations in central Nevada, for the month of October 1972. This is the fourth in a series of monthly seismicity reports, Bayer (1972), embracing southern Nevada and the border zones of Arizona, California, and Utah.

The southern Nevada seismic network station locations a re shown in figure 1. All stations are located in Nevada with the exception of Leeds (LEE) in Utah, and Darwin (DAC) in California. This net is operated by the three cooperating agencies listed in table 1. The data from all of the stations a re recorded on $16 \mathrm{~mm}$ film and magnetic tape by the Nevada Special Projects Party (NSPP) of the National Oceanic 


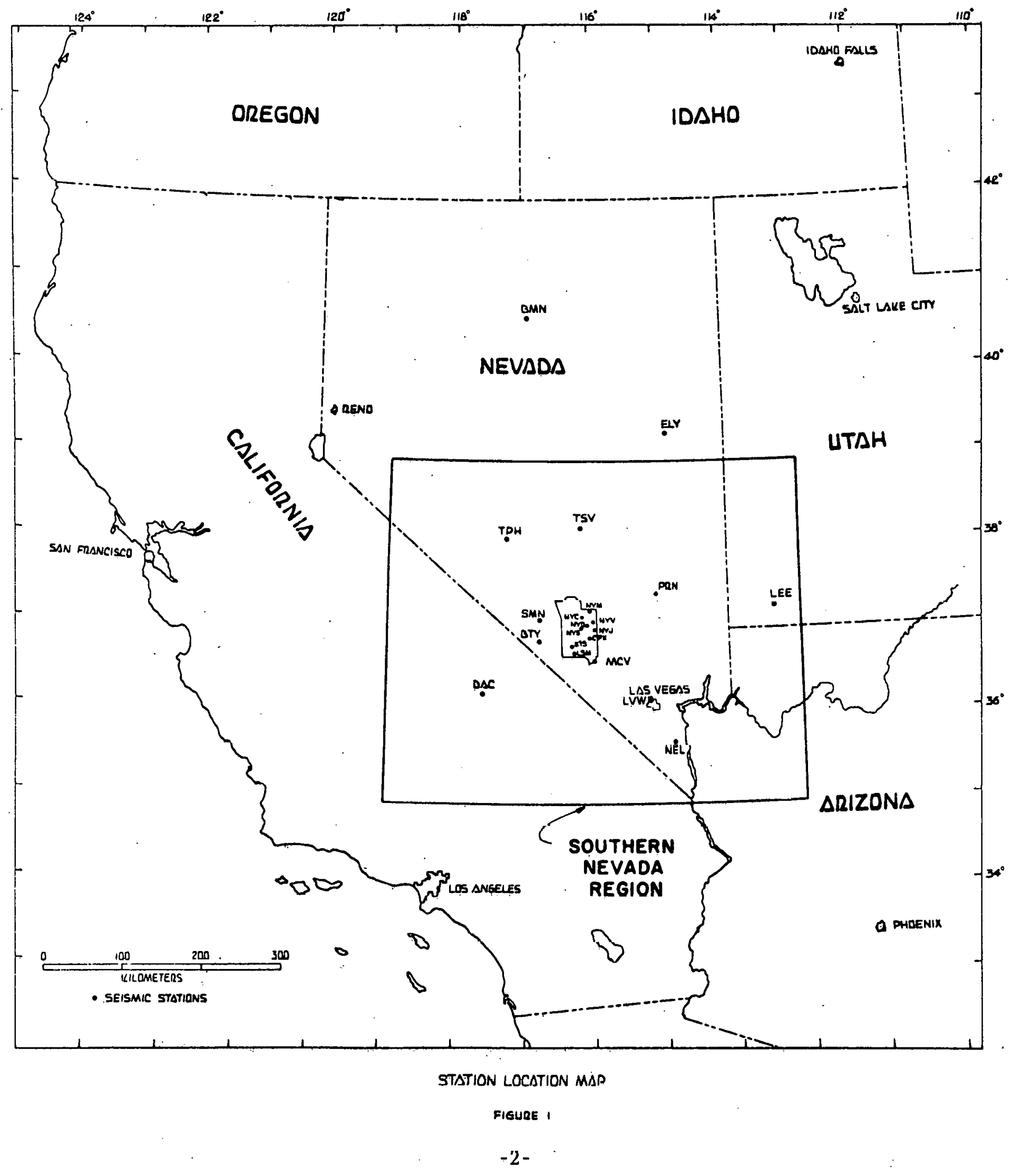


TABLE I

SEISMIC $\$$ TATION CONSTANTS

\begin{tabular}{ccccccc}
\hline Code & *Station & Latitude & Longitude & Elev. & Inst. & Approx. Magni- \\
(West) & (Meters) & Comp. & fication @ 1 Hz \\
\hline
\end{tabular}

NOAA/ESL/NEVADA SEISMOGRAPH STATIONS

$\begin{array}{lllllll}\text { BTY } & \text { Beatty } & 36^{\circ} 53.63^{\prime} & 116^{\circ} 45.88^{\prime} & 1008 & \text { SPZ } & 100 \mathrm{~K} \\ \text { CPX } & \text { CP-1 (Control Point \#1) } & 36^{\circ} 55.92^{\prime} & 116^{\circ} 03.33^{\prime} & 1285 & \text { SPZ } & 110 \mathrm{~K} \\ \text { ETS } & \text { Engine Test Stand } & 36^{\circ} 49.95^{\prime} & 116^{\circ} 18.50^{\prime} & 1158 & \text { SPZ } & 0.1 \mathrm{~K} \\ \text { LSM } & \text { Little Skull Mountain } & 36^{\circ} 44^{\prime} 2^{\prime} & 116^{\circ} 16.68^{\prime} & 1146 & \text { SPZ } & 220 \mathrm{~K} \\ \text { LVW } & \text { Las Vegas (West) } & 36^{\circ} 10^{\prime} .20^{\prime} & 115^{\circ} 11.25^{\prime} & 654 & \text { SPZ } & 3.3 \mathrm{~K} \\ \text { MCV } & \text { Mercury } & 36^{\circ} 38.01^{\prime} & 115^{\circ} 59.99^{\prime} & 1158 & \text { SPZ } & 100 \mathrm{~K} \\ \text { PRN } & \text { Pahroc Range } & 37^{\circ} 26.50^{\prime} & 115^{\circ} 04.00^{\prime} & 1524 & \text { SPZ } & 105 \mathrm{~K} \\ \text { SMN } & \text { Sleeping Mountain } & 37^{\circ} 08.60^{\prime} & 116^{\circ} 46.00^{\prime} & 1246 & \text { SPZ } & 25 \mathrm{~K} \\ \text { TSV } & \text { Twin Springs } & 38^{\circ} 12.10^{\prime} & 116^{\circ} 10.50^{\prime} & 1585 & \text { SPZ } & 105 \mathrm{~K}\end{array}$

SANDIA LABORATORIES STATIONS

$\left.\begin{array}{llllll}\text { BMN } & \text { Battle Mountain } & 40^{\circ} 25.90^{\circ} & 117^{\circ} 13.30^{\prime} & 1524 & \text { SPZ } \\ \text { DAC } & \text { Darwin, California } & 36^{\circ} 16.62^{\prime} & 117^{\circ} 35.62^{\prime} & 1432 & \text { SPZ } \\ \text { ELY } & \text { Ely } & 39^{\circ} 07.88^{\prime} & 114^{\circ} 53.52^{\prime} & 2012 & \text { SPZ } \\ \text { LEE } & \text { Leeds, Utah } & 37^{\circ} 14.58^{\prime} & 113^{\circ} 22.60^{\prime} & 1067 & \text { SPZ } \\ \text { NEL } & \text { Nelson } & 35^{\circ} 42.74^{\prime} & 114^{\circ} 50.61^{\prime} & 1052 & \text { SPZ } \\ \text { TPH } & \text { Tonopah } & 38^{\circ} 04.29^{\prime} & 17^{\circ} 13.21^{\prime} & 1890 & \text { SPZ }\end{array}\right\}$ Variable

U. S. GEOLOGICAL SURVEY, YUCCA FLATS NEVADA STATIONS

\begin{tabular}{|c|c|c|c|c|c|c|}
\hline NYC & Charley & $37^{\circ} 09.30^{\prime}$ & $116^{\circ} 09.32^{\circ}$ & 1574 & SPZ & \\
\hline $\mathrm{NYJ}$ & Joshua Tree & $37^{\circ} 00.48^{\circ}$ & $115^{\circ}, 58.48^{\circ}$ & 1195 & SPZ & \\
\hline NYM & Climax Mine & $37^{\circ} 13.88^{\circ}$ & $116^{\circ} 03.14^{\circ}$ & 1489 & SPZ & $1000 \mathrm{~K}$ \\
\hline NYR & Receiver Site & $37^{\circ} 03.32^{\prime}$ & $116^{\circ} 05.50^{\circ}$ & 1188 & SPZ & (20X Viewer) \\
\hline NYS & Syncline Ridge & $37^{\circ} 01.95^{\prime}$ & $116^{\circ} 10.13^{\prime}$ & 1402 & SPZ & \\
\hline NYV & Vern & $37^{\circ} 06.77^{\prime}$ & $115^{\circ} 59.40^{\prime}$ & 1340 & SPZ & \\
\hline
\end{tabular}

* Location in Nevada, unless otherwise specified. 
and Atmospheric Adminịstration/Earth Sciences Laboratories (NOAA/ESL), Las Vegas, Nevada. The Hypocenter Summary (Appendix A) is the result of programming only data from the Nevada network to compute ea rthquake locations.

\section{DISCUSSION}

The principal objective of the monthly report is to distribute preliminary seismic data acquired from the Southern Nevada Network of Seismograph Stations. A more comprehensive bi-annual seismicity report similar to Bayer (1972) is planned for publication at a later time.

Recorded arrival times and amplitudes are scaled in Las Vegas. Periodically, the properly formatted data are keypunched at the Las Vegas office and run through a local earthquake program described by Bolt, et al. (1964), using a three-layer model. In order to obtain a hypocenter solution with the local station program, Pphase arrival times from at least three stations and one S-phase arrival time for a given earthquake must be present. This compilation is preliminary and may be subject to later revision on the basis of current research.

The individual station readings, from which the hypocenter summary has been derived, are available upon request from the ESL Nevada Special Projects Party, 3060 South Highland Drive, Las Vegas, Nevada 89109. The phase times are also sent to the National Earthquake Information Center (NEIC) Boulder, Color ado, on punch cards in the NEIC format. The a rea monitored by the NSPP (for hypocenter locations), is from 35 to 39 degrees north and 113 to 119 degrees west (see fig. 1). Seismic body wave phases from earthquakes which fall in the regional and teleseismic range are also scaled and mailed to the NEIC. 
In the Hypocenter Summary, a "D" following the depth indicates it is a fixed depth solution obtained by choosing the 5 kilometer depth interval that optimized the travel time residuals and standard error. An " $F$ " following the depth indicates the computer found a convergent solution in seven or less iterations by permitting the depth to move freely.

\section{GENERAL SEISMICITY}

Ea rthquakes recorded and located in the southern Nevada region during the month of October 1972 continued at an increased rate over the previous month; particularly in the Twin Springs, Nevada area, east of Alamo, Nevada, and west of Scotty's Junction, at the north termination of Death Valley in California. A total of 93 earthquakes were located by the NSPP. All earthquakes plotted on the seismicity map (fig. 2), occurred within the earth's crust. Maximum hypocentral depth was $25 \mathrm{~km}$, well above the Mohorovicic discontinuity. A preliminary evaluation of magnitude suggests the great majority of the located events were microearthquakcs $(1.0 \leq M \leq 3.0)$

Southern Nevada. The most active area during the month was from northeast of Hiko Junction to southeast of Alamo. A total of 25 earthquakes were located in this area. The greatest concentration of shocks was in the Delamar Mountains approximately $30 \mathrm{~km}$ southeast of Alamo. Remaining activity was scattered through out the Dry Lake Valley, Delamar Valley, and to the east in the Meadow Valley Mountains.

The Twin Springs area was quite active during the month with 14 earthquakes located in all but the southwest quadrant. Eight quakes occurred northwest of 


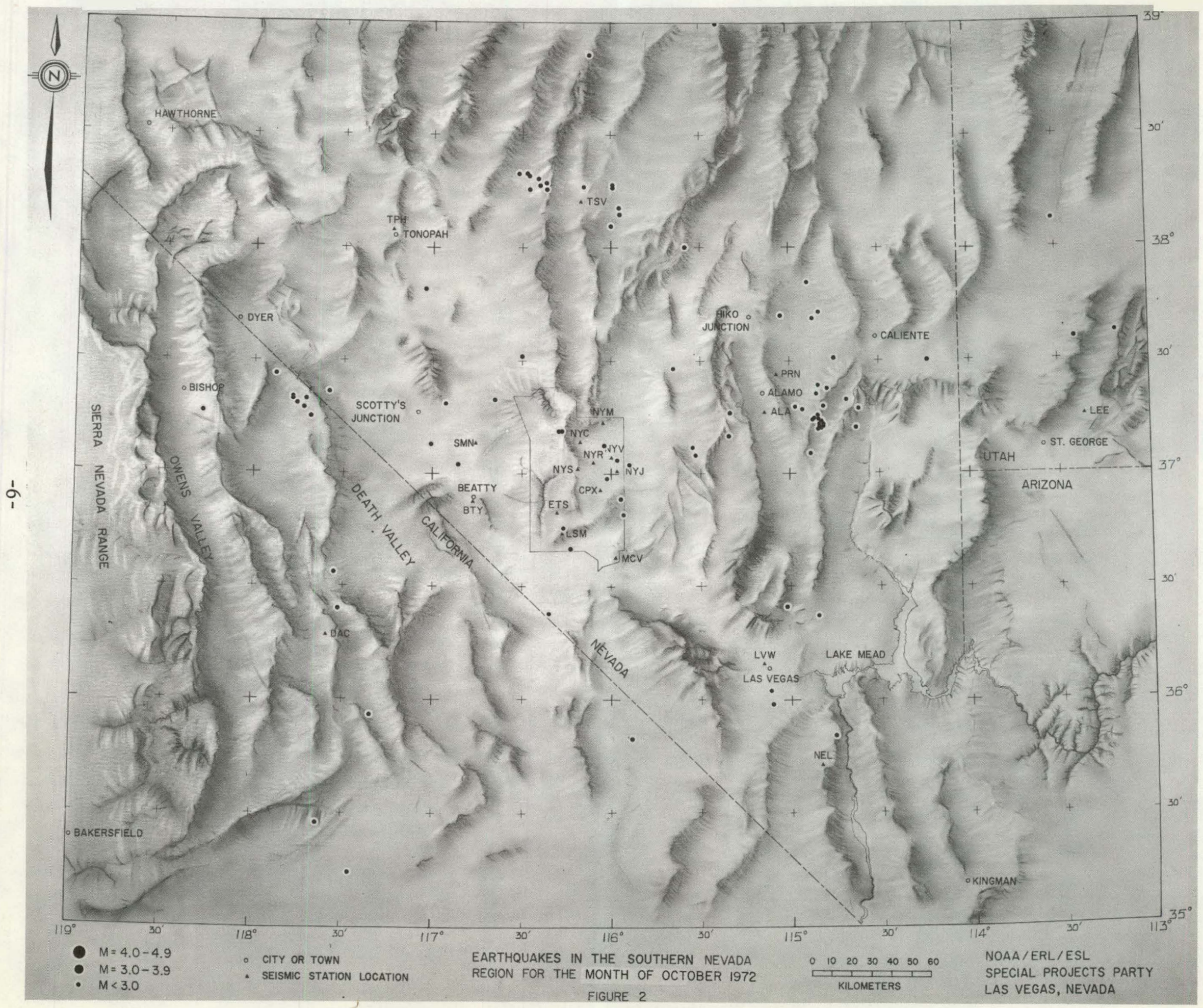


station TSV between the Hot Creek and Monitor Ranges. Most of the remaining activity was located southeast to northeast of Twin Springs on the west flank of the Quinn Canyon Range.

There were 10 earthquakes on and immediately adjacent to the Nevada Test Site, as shown on figure 3. The numbers adjacent to the earthquake symbol indicate the Greenwich Mean Time (GMT) date of origin. The quakes plot in a random manner and do not suggest strain relea se on or adjacent to the larger known fault systems.

Two earthquakes were located 15 and $20 \mathrm{~km}$ south of Las Vegas on the northwest flank of the McCullough Range. A third shock of unusual location wa s located about $20 \mathrm{~km}$ south of Hoover Dam, on the west side of the Colorado River, in the Eldorado Mountains. Two earthquakes occurred approximately $35 \mathrm{~km}$ northeast of Las Vegas on the south end of Hidden Valley and Dry Lake Valley.

Southeast California Area. Last Chance Range along the northern extremity of Death Valley and Eureka Valley to the west, continued as the most active sector in the California border zone. Owens Valley remained a relatively inactive area during the month. A total of 14 earthquakes were located in the California area during the month.

Southwest Utah and Northwest Arizona. Only three earthquakes were located in Utah; two west and southwest of Cedar City in the Antelope and Cedar Mountains and a third farther to the north on the southeast termination of the Wah Wah Mountains. There was no recorded activity in the border zone of Arizona.

There were no announced nuclear or HE events on the NTS for the month of October 1972. 


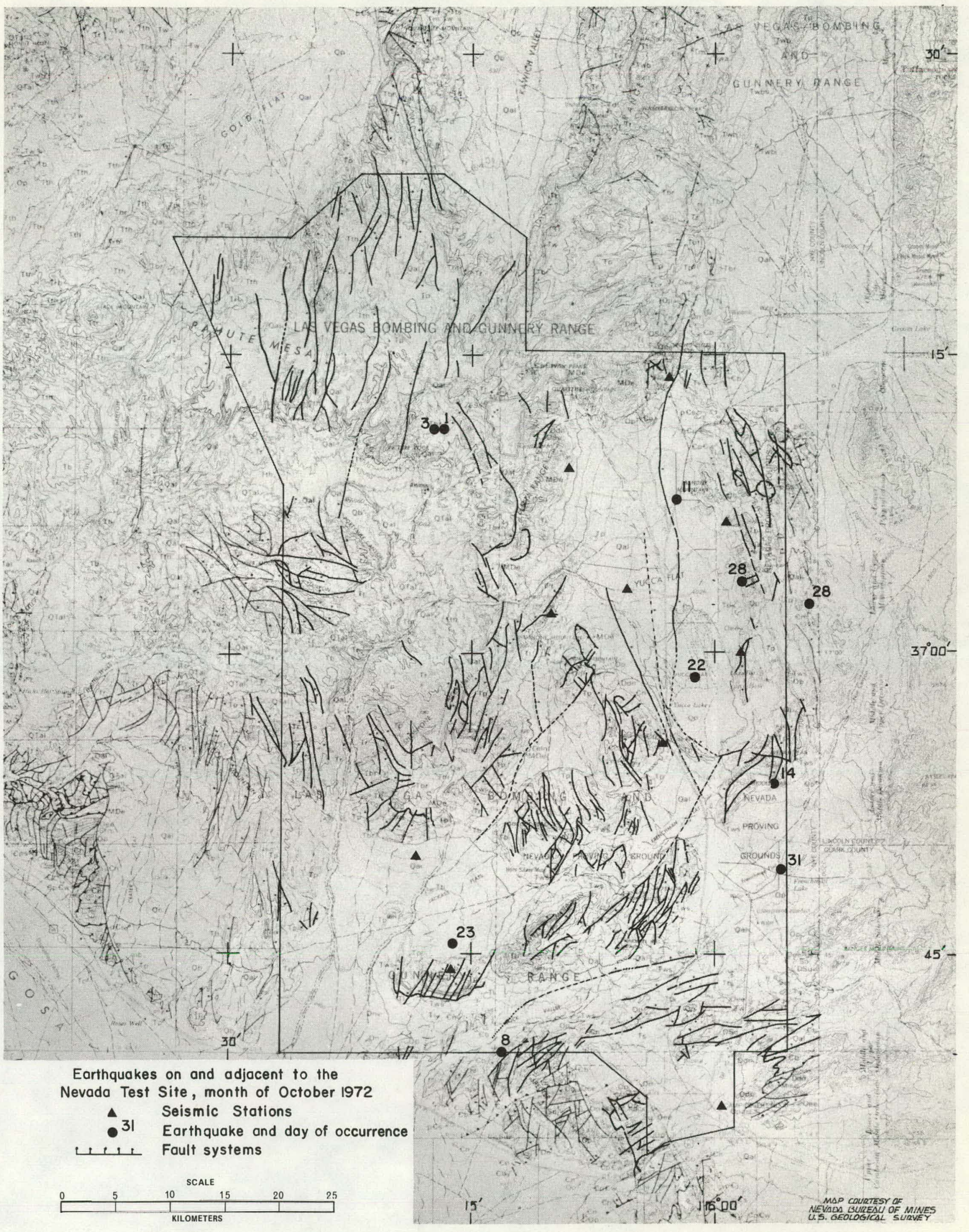

Figure 3 


\section{ACKNOWLEDGMENTS}

The entire staff of the Nevada Special Projects Party participated in the operation and coordination of the NOAA/ESL seismograph network. Without the cooperation of the Sandia Laboratories and the U. S. Geological Survey, a large portion of the data that went into this report would not be available. The author expresses grateful acknowledgment to Kenneth W. King, Chief of Party, for administrative support, to Stanley R. Brockman for the computer processing, and to Bruce R. Bradley fọ data plotting and map compilation.

The operation of all the seismograph stations and the interpretations of the data from these stations are made possible through the financial support of the Nevada Operations Office of the United States Atomic Energy Commission (NVO/AEC), under Memorandum of Agreement AT(29-2)-746.

\section{REFERENCES}

Bayer, K, C. (1972), Seismicity of the southern Nevada region, December 22, 1971 to July 1, 1972, NVO-746-3, July.

Bayer, K. C. (1972), A preliminary seismicity study of the southern Nevada region for the month of July 1972, NVO-746-4, September.

Bolt, B. A., and T. Turcotte (1964), Computer location of local earthquakes within the Berkeley seismograph network, computers in the mineral industries, Stanford Univic rsity, 561 . 
APPENDIX A

OCTOBER 1972 HYPOCENTER SUMMARY 
A P PENDIX A

OCTOBER 1972, HYPOCENTER SUMMARY

\begin{tabular}{|c|c|c|c|c|c|c|}
\hline No. & Day & $\begin{array}{l}\text { Origin Time } \\
\text { GMT }\end{array}$ & $\begin{array}{c}\text { Latitude } \\
\text { North }\end{array}$ & $\begin{array}{c}\text { Longitude } \\
\text { West }\end{array}$ & $\begin{array}{c}\text { Depth* } \\
(\mathrm{km})\end{array}$ & $\begin{array}{c}\text { Geographic } \\
\text { Area } \\
\end{array}$ \\
\hline 1 & 01 & $\quad 052808.83$ & $37.19^{\circ}$ & $116.28^{\circ}$ & $05.0 \mathrm{D}$ & Silent Canyon \\
\hline 2 & 01 & 064702.95 & 37.27 & 118.29 & $05.0 \mathrm{D}$ & Blanco Mtn. \\
\hline 3 & 01 & 1147.15 .16 & 36.56 & 117.55 & $15.0 \mathrm{D}$ & Dry Mtn. \\
\hline 4 & 01 & 124831.32 & 35.93 & 117.34 & $14.7 \mathrm{~F}$ & Searles Lake \\
\hline 5 & 03 & 132236.49 & 37.19 & 116.29 & $05.0 \mathrm{D}$ & Silent Canyon \\
\hline 6 & 03 & $18 \quad 1552.78$ & 37.52 & 116.50 & $10.0 \mathrm{D}$ & Quartzite Mtn. \\
\hline 7 & 03 & $21 \quad 1213.22$ & 38.28 & 116.40 & $15.0 \mathrm{D}$ & Warm Springs \\
\hline 8 & 04 & 211213.64 & 38.26 & 116.46 & $25.0 \mathrm{D}$ & Warm Springs \\
\hline 9 & 05 & 222052.50 & 35.98 & 115.10 & $05.0 \mathrm{D}$ & Goodsprings \\
\hline 10 & 06 & 002250.54 & 37.27 & 115.33 & $25.0 \mathrm{D}$ & Alamo \\
\hline 11 & 06 & $0402 \quad 10.44$ & 37.50 & 114.23 & 0.0 .0 & Tule Desert \\
\hline 12 & 06 & 110812.96 & 35.46 & 117.63 & $05.0 \mathrm{D}$ & Boron \\
\hline 13 & 06 & 213248.09 & 37.60 & 113.40 & $10.0 \mathrm{D}$ & Cedar City \\
\hline 14 & $1) 6$ & $22 ১ 159.89$ & 35.84 & 114.76 & $15.0 \mathrm{D}$ & Boulder City \\
\hline 15 & 06 & 231709.58 & 39.00 & 115.40 & $20.0 \mathrm{D}$ & Currant Mtn. \\
\hline 16 & 07 & 012203.39 & 37.82 & 117.04 & $25.0 \mathrm{D}$ & Goldfield \\
\hline $1 \%$ & 07 & 035333.09 & 37.33 & 117.71 & $10.0 \mathrm{D}$ & Magruder Mitn. \\
\hline 18 & 07 & 141707.42 & 36.40 & 117.52 & $00.0 \mathrm{D}$ & Darwin \\
\hline 19 & 07 & 211645.89 & 38.26 & 116.36 & $00.0 \mathrm{D}$ & Warm Springs \\
\hline 20 & 08 & $\mathrm{Cl} 2131.22$ & 38.33 & 116.47 & $05.0 \mathrm{D}$ & Warm Springs \\
\hline
\end{tabular}


APPENDIX A

OCTOBER 1972 HYPOCENTER SUMMARY

\begin{tabular}{|c|c|c|c|c|c|c|c|}
\hline No. & Day & $\begin{array}{c}\text { Origin Time } \\
\text { GMT }\end{array}$ & $\begin{array}{c}\text { Latitude } \\
\text { North }\end{array}$ & & $\begin{array}{c}\text { Longitude } \\
\text { West }\end{array}$ & $\begin{array}{l}\text { Depth } \\
(\mathrm{km})\end{array}$ & $\begin{array}{c}\text { Geographic } \\
\text { Area }\end{array}$ \\
\hline 21 & 08 & 024826.48 & $38,00^{\circ}$ & & $115.58^{\circ}$ & $05.0 \mathrm{~F}$ & Worthington Peak \\
\hline 22 & 08 & 044731.34 & 36.67 & & 116.22 & $01.1 \mathrm{~F}$ & Lathrop Wells \\
\hline 23 & 08 & 095518.94 & 37.13 & & 117.01 & $12.4 \mathrm{~F}$ & Mt. Jackson \\
\hline 24 & 08 & 172548.86 & 38.15 & & 115.95 & $20.0 \mathrm{D}$ & Troy Canyon \\
\hline 25 & 08 & 192534.35 & 35.83 & & 115.88 & $25.0 \mathrm{D}$ & Clark Mtn. \\
\hline 26 & 09 & 093753.56 & 37.33 & & 117.78 & $07.1 \mathrm{~F}$ & Magruder Mtn. \\
\hline 27 & 10 & 035956.61 & 37.33 & & 117.78 & $15.0 \mathrm{D}$ & Magruder Mtn. \\
\hline 28 & 10 & 070513.11 & 37.25 & & 117.68 & $00.0 \mathrm{~F}$ & Magruder Mtn. \\
\hline 29 & 10 & 080555.51 & 37.31 & & 117.76 & $05.0 \mathrm{D}$ & Magruder Mtn. \\
\hline 30 & 10 & 114041.99 & 37.29 & & 117.72 & $10.0 \mathrm{D}$ & Magruder Mtn. \\
\hline .31 & 1.0 & 115552.68 & 37.36 & & 117.58 & $25.0 \mathrm{D}$ & Magruder Mtn. \\
\hline 32 & 10 & 120200.36 & 37.04 & & 116.85 & $00.0 \mathrm{D}$ & Thirsty Canyon \\
\hline 33 & 10 & 124721.63 & 37.12 & & 115.54 & $19.6 \mathrm{~F}$ & Groom Lake \\
\hline 34 & 11 & 014720.16 & 37.13 & & 116. 04 & $25.0 \cap$ & Silent Canyon \\
\hline 35 & 11 & 205033.32 & 38.33 & & 116.52 & $00.0 \mathrm{D}$ & Black Butte \\
\hline 36 & 12 & 013954.67 & 37.24 & & 114.86 & $00.0 \mathrm{D}$ & Delamar Mts. \\
\hline 37 & 12 & 084911.23 & 37.24 & & 114.87 & $00.0 \mathrm{D}$ & Delamar Mts. \\
\hline 38 & 12 & 131232.19 & 38.32 & & 115.16 & $10.0 \mathrm{D}$ & Warm Springs \\
\hline 39. & 12 & 144207.03 & 38.18 & & 115.96 & $20.0 \mathrm{D}$ & Troy Canyon \\
\hline 40 & 13 & 160432.15 & 37.17 & & 115.34 & $25.0 \mathrm{D}$ & Alamo \\
\hline
\end{tabular}


A PPENDIX A

OCTOBER 1972 HYPOCENTER SUMMARY

\begin{tabular}{|c|c|c|c|c|c|c|}
\hline No. & Day & $\begin{array}{l}\text { Origin Time } \\
\text { GMT }\end{array}$ & $\begin{array}{c}\text { Latitude } \\
\text { North }\end{array}$ & $\begin{array}{c}\text { Longitude } \\
\text { West }\end{array}$ & $\begin{array}{l}\text { Depth* } \\
\text { (km) }\end{array}$ & $\begin{array}{c}\text { Geographic } \\
\text { Area } \\
\end{array}$ \\
\hline 41 & 13 & $21 \quad 18 \quad 15.14$ & $38.28^{\circ}$ & $115.99^{\circ}$ & $10.0 \mathrm{D}$ & Troy Canyon \\
\hline 42 & 13 & 214209.84 & 38.27 & 115.99 & $10.0 \mathrm{D}$ & Troy Canyon \\
\hline 43 & 14 & 073526.06 & 38.29 & 116.36 & $00.0 \mathrm{D}$ & Warm Springs \\
\hline 44 & 14 & 074910.51 & 38.31 & 116.41 & $10.1 \mathrm{~F}$ & Warm Springs \\
\hline 45 & 14 & 133015.10 & 36.89 & 115.94 & $05.0 \mathrm{D}$ & Mercury \\
\hline 46. & 14 & 152501.77 & 37.33 & 116.65 & $00.0 \mathrm{D}$ & Thirsty Canyon \\
\hline 47. & 14 & 161144.02 & 37.51 & 114.75 & $18.2 \mathrm{~F}$ & Highland Peak \\
\hline 48 & 14 & 163730.57 & 36.41 & 115.02 & $05.0 \mathrm{D}$ & Las Vegas \\
\hline 40 & 14 & 183554.30 & 38.10 & 116.00 & $20.0 \mathrm{D}$ & Warm Springs \\
\hline 50 & 16 & 073330.57 & 37.70 & 115.05 & $15.8 \mathrm{~F}$ & Hiko \\
\hline 51. & 16 & 220751.40 & 35.24 & 117.46 & $10.0 \mathrm{D}$ & Opal Mtn. \\
\hline 52 & $17^{\circ}$ & 083955.38 & 38.86 & 116.12 & $10.0 \mathrm{D}$ & Morey Peak \\
\hline 53. & 17 & 102744.13 & 37.22 & 114.83 & $00.0 \mathrm{D}$ & Dclamar Mts. \\
\hline 54. & 17 & 124642.07 & 37.21 & 114.63 & $15.0 \mathrm{D}$ & Delamar Mts. \\
\hline 55. & 17 & 152738.22 & 37.33 & 114.68 & $10.0 \mathrm{D}$ & Delamar Mts. \\
\hline 56. & 17 & 192202.28 & 38.27 & 116.15 & $10.0 \mathrm{D}$ & Warm Springs \\
\hline 57. & 17 & 233501.00 & 37.62 & 113.18 & $15.0 \mathrm{D}$ & Cedar City \\
\hline 58. & 19 & 051722.45 & 37.44 & 117.88 & $10.0 \mathrm{D}$ & Magruder Mtn. \\
\hline 59. & 19 & 164258.46 & 37.26 & 114.84 & $00.0 \mathrm{D}$ & Delamar Mts. \\
\hline 60. & 20 & 183806.62 & 36.37 & 114.85 & $00.0 \mathrm{~F}$ & Hoover Dam \\
\hline
\end{tabular}


APPENDIX A

OCTOBER 1972 HYPOCENTER SUMMARY

\begin{tabular}{|c|c|c|c|c|c|c|}
\hline No. & Day & $\begin{array}{l}\text { Origin Time } \\
\text { GMT }\end{array}$ & $\begin{array}{l}\text { Latitude } \\
\text { North }\end{array}$ & $\begin{array}{c}\text { Longitude } \\
\text { West }\end{array}$ & $\begin{array}{l}\begin{array}{l}\text { Depth* } \\
(\mathrm{km})\end{array} \\
\end{array}$ & $\begin{array}{l}\text { Geographic } \\
\text { Area }\end{array}$ \\
\hline 61. & 20 & $23 \quad 1232.45$ & $38.13^{\circ}$ & $113.52^{\circ}$ & $00.0 \mathrm{D}$ & Indian Peak \\
\hline 62. & 21 & $06 \quad 1436.79$ & 37.47 & 115.65 & $05.0 \mathrm{D}$ & Groom Lake \\
\hline 63. & 21 & $2235 \quad 11.07$ & 37.08 & 115.53 & $00.0 \mathrm{~F}$ & Groom Lake \\
\hline 64. & 22 & 044547.13 & 37.09 & 114.88 & $20.0 \mathrm{D}$ & Delamar Mts. \\
\hline 65. & 22 & 114924.95 & 37.23 & 114.82 & $05.0 \mathrm{D}$ & Delamar Mts. \\
\hline 66. & 22 & 123330.75 & 37.29 & 114.61 & $10.0 \mathrm{D}$ & Delamar Mts, \\
\hline 67. & 22 & 143326.30 & 36.98 & 116.02 & $08.9 \mathrm{~F}$ & Lathrop Wells \\
\hline 68. & 23 & 021348.26 & 36.76 & 116.27 & $05.0 \mathrm{D}$ & Lathrop Wells \\
\hline 69. & 23 & 080209.33 & 37.20 & 114.84 & $00.0 \mathrm{D}$ & Delamar Mts. \\
\hline 70. & 23 & 083048.43 & 37.69 & 114.87 & $25.0 \mathrm{D}$ & Highland Peak \\
\hline 71. & 23 & 145058.92 & 37.31 & 116.93 & $05.0 \mathrm{D}$ & Thirsty Canyon \\
\hline 72. & 23 & 151127.55 & 37.38 & 114.79 & $15.0 \mathrm{D}$ & Delamar Mts. \\
\hline 73. & 23 & 193958.71 & 37.28 & 114.93 & $00.0 \mathrm{D}$ & Delamar Mts. \\
\hline 74. & 24 & 055019.60 & 37.29 & 114.97 & $00.0 \mathrm{D}$ & Delamar Mts. \\
\hline 75. & 24 & 132147.49 & 37.22 & 114.81 & $00.0 \mathrm{D}$ & Delamar Mts. \\
\hline 76. & 27 & 065321.32 & 36.38 & 116.35 & 20. O.D & Ash Meadows \\
\hline 77. & 27 & 082609.13 & 36.04 & 115.11 & $15.6 \mathrm{~F}$ & Las Vegas \\
\hline 78. & 27 & 153325.17 & 37.24 & 114.84 & $00.0 \mathrm{D}$ & Delamar Mts. \\
\hline 79. & 28 & 190124.98 & 37.26 & 114.84 & $17.5 \mathrm{~F}$ & Delamar Mts. \\
\hline 80. & 28 & 211756.95 & 37.04 & 115.90 & $13.5 \mathrm{~F}$ & Groom Lake \\
\hline
\end{tabular}


APPENDIX A

OCTOBER 1972 HYPOCENTER SUMMARY

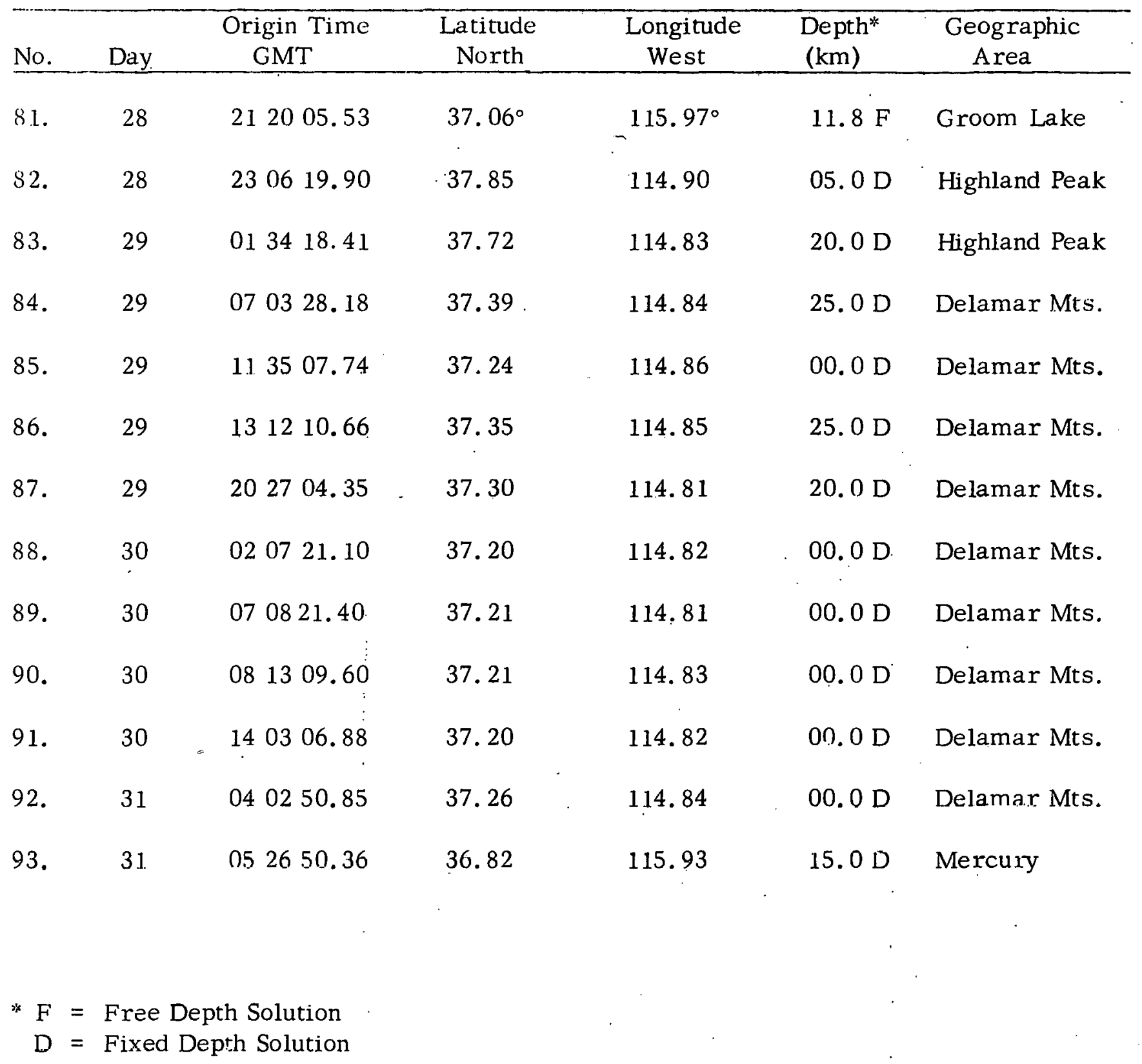


Distribution:

Nevada Operations Office, U. S. Atomic Energy Commission, Las Vegas, Nevada

DiBona, B. G.

Douthett, E. M.

Halstead, P. N.

Kinnaman, R. L.

Lowr, R. R.

Technical Library (3)

NVOO Panel of Consultants

Bustad, L. K., University of California, Davis, California 9.5616

Deere, D. U., 2552 S. W. 14th Dr. , Gai nsville, Florida 36201

Jacobsen, L. S., 267 Belgreen Place, Oakmont, Santa Rosa, California 95405

Kisslinger, C. , University of Colorado, Boulder, Colorado 80302

Lintz, J. , University of Nevada, Reno, Nevada 89507

Newmark, N. M., University of Illinois, Urbana; Illinois 61801

Schulz, V., Washington State University, Pullman, Washington 99163

Thompson, T. F., 713 Crossway Road, Burlingame, California 94010

Van Dorn, W. G., Scripps Institute of Oceanography, La Jolla, California 92037

Von Lossberg, L. G., Sheppard T. Powell \& Associates, Baltimore, Maryland 21201

Wilson, J. T., University of Michigan, Ann A rbor, Michigan 48105

Witherspoon, T. A., University of California, Berkeley, California 91109

National Oceanic \& Atmospheric Administration, ERL/ESL

Algermissen, S. T., Boulder, Colorado 80302

Alldredge, L. R., Boulder, Colorado 80302

Jordan, J. N., Boulder, Colorado 80302

Lander, Jo li., NEIC, Boulder, Colorado 80302

Matthiesen, R. B., San Francisco, California 94105

Mickey, W. V., Boulder, Colorado 80302

Murphy, L. M., Boulder, Colorado 80302

Tocher, D. , San Francisco, California 94105 (2)

Von Hake, C., EDS D/62/S, 1135 Broadway, Boulder, Colorado 80302 
Distribution (cont'd)

Advanced Research Projects Agency, Arlington, Virginia 20301

Lukasik, S. J.

AFTAC/VELA Seismological Center, Alexandria, Virginia 22314

Pilotte, F. F.

Air Force Office, Scientific Research, Arlington, Virginia 22209

Best, W. J.

Blume, John A. and Associates Engineers, San Francisco, California 94105

Blume, John A. and Associates Research Division, Las Vegas, Nevada 89109

California Institute of Technology, Pasadena, California 91109

Allen, C. R.

Anderson, D.

Nordquist, J.

CER, Geonuclear Corporation, Las Vegas, Nevada 89114

Alcock, E. D.

Colorado School of Mines, Golden, Colorädo 80401

Major, M. W.

Romig, P.

Simon, Ruth B.

Corncll University, Ithaca, New York 14850

Oliver, J.

Detense Atomic Support Agency, Sandia Base, Albuquerque; New Mexico 87115

Grote, B.

Environmental Resea rch Corporation, Las Vegas, Nevada 89102

Hays, W. W. (2) 
Distribution (cont'd)

Lamont Doherty Geological Observatory, Palisades, New York 10964

Sykes, L.

Lawrence-Livermore Laboratory, Livermore, California 94551

Carothers, P. C.

Coyle, P. E.

Germain, L. S.

Hadley, J. W.

Rodean, H. C.

Technical Information Library

Lawrence-Livermore Laboratory, Mercury, Nevada

McArthur, R. D.

Los Alamos Scientific Laboratory, Los Alamos, New Mexico 87544

Browne,C. I. (3)

Massachusetts Institute of Technology, Cambridge, Massachusetts 02139

A ki, K.

Toksoz, M. N.

Medearis, Kenneth \& Associates, Ft. Collins, Colorado 80521

Medearis, $\mathrm{K}$.

Sandia Laboratories, Albuquerque, New Mexico 87115

Banister, J. R.

Ellett, D. M.

Merritt, M. L.

Sandia Technical Libraries (2)

Tendall, D. M.

Weart, W. E.

Sandia Laboratories, Mercury, Nevada.

Brady, L. F. 
Distribution (cont'd)

St. Louis University, St. Louis, Missouri 63103

Stauder, W. J.

Technical Information Center, U. S. Atomic Energy Commission

Oak Ridge, Tennessee 37830 (2).

University of California, Berkeley, California 91109

Bolt, B.

Cloud, W. K

University of Nevada, Reno, Nevada 89507

Ryall, A.

University of Utah, Salt Lake City, Utah 84112

Cook, K. L.

University of Wisconsin, Milwaukee, Wisconsin 53201

Willis, D. E.

U. S. Atomic Energy Commission, Washington, D. C. 20545

Diles, M. B. (DOS)

Camm, Major Gen. Frank A., Hq. (DMA) (3)

Hamburger, R. (DAT)

U. S. Geological Survey, Menlo Park, California 94025

Healy, J. (2) 